INDEPENDENT JOURNAL OF MANAGEMENT \& PRODUCTION (IJM\&P) http://www.ijmp.jor.br

v. 12, n. 2, March-April 2021

ISSN: 2236-269X

DOI: 10.14807/ijmp.v12i2.1297

\title{
PAYROLL TAXES INCREASE RESERVES IN UKRAINE
}

Nataliia Volodymyrivna Ivanchuk The National University of Ostroh Academy, Ukraine E-mail: natalia.ivanchuk@oa.edu.ua

Nataliia Anatoliivna Mamontova The National University of Ostroh Academy, Ukraine E-mail: nataliya.mamontova@oa.edu.ua

Submission: 2/29/2020

Revision: 5/13/2020

Accept: 6/3/2020

\section{ABSTRACT}

The authors analyzed the reformation of the payroll taxation mechanism in Ukraine, identified wage differences of the employees at the large, medium-sized and small business entities, figured out the reserves to increase tax revenues and cover the deficit of the Pension Fund of Ukraine by decreasing shadow wages and improving payroll taxation in Ukraine. Significant attention is paid to the salaries of the top managers of large business entities as a possible field of applying progressive taxation of personal income. Based on the analysis of the EU countries experience, the authors suggest imposing the second progressive personal income tax rate of 32\% for the monthly income that exceeds 15 minimum wages. As well, the abolishment of the maximum unified social contribution base is recommended. In the paper, the authors prove the importance of reducing the level of the shadow economy in Ukraine by forming a public trust to the government policy and using accumulated tax funds appropriately. It has been proved that by reducing the shadowing of the Ukrainian economy to the EU level, the deficit of the Pension Fund of Ukraine can be covered only partially. This fact determines the necessity for Ukraine to ensure economic growth and increase wages.

Keywords: payroll taxation; personal income tax; unified social contribution; shadow economy 
DOI: 10.14807/ijmp.v12i2.1297

\section{INTRODUCTION}

At the present stage of the economic development of Ukraine, the optimization of taxation processes of economic entities is an important precondition for stimulating production and business activity. Paying taxes causes the loss of a taxpayer's financial interest in their work, reduces incentives for further expansion, and makes payer conceal some of their revenues and expenses.

Labour relations in Ukraine are characterized by a significant amount of hidden payroll that can serve an important tax base. The reform of the domestic economy deals with the improvement of tax relations, and considerable attention is paid to the mechanism of payroll taxation. These measures are taken to reduce the shadow wages and increase tax revenues that can become the source of income to the state social insurance funds, state and local budgets of Ukraine.

There have been numerous suggestions on how to improve payroll taxation in Ukraine and to reduce concealment of the payroll.

In particular, scientists point out that one of the biggest problems putting the brakes on the Ukrainian economy is "shadowing" of the domestic business and wage payments. Therefore, to remove wages from the shadow, Ukraine needs to turn back to a progressive scale of personal income taxation, reduce the tax burden in the least protected segments of the population and increase it for the persons receiving high incomes. Besides, it is necessary to impose a differentiated minimum rate of the unified social contribution for the various categories of employees, without any additional restrictions, to reduce the rate of the contribution and to determine the minimum amount of pension in the proportion to the duration of compulsory seniority has worked for the retirement (Boreiko, 2015).

Scientists systematize the main ways to legalize remuneration of labour, which include reducing the tax and social contribution burden, increasing the correlation between paid social security contributions and the size of the pension, redistribution of social security contributions between the employee and employer. It is as well necessary to increase the responsibility for tax and social security contribution evasion, improve tax administration, introduce the indicative wages, improve the quality of social services (Sanduhei, 2017).

De-shadowing of the labour market is considered to be a top priority task for the government. To fulfil the task, one should simplify tax administration system and tax legislation, prohibit tax changes for five years, reduce the payments to social security funds, 
DOI: 10.14807/ijmp.v12i2.1297

improve the quality of public services and reduce the number of tax benefits (Danylyshyn \& Stefankiv, 2011).

It is urgent to apply a comprehensive approach to wages de-shadowing, using a set of administrative, economic and legal factors. In doing so, we should take into account the interests of the state, employers and employees. Direct active involvement of employees can help solve the problem of wage legalization (Kulikov, 2016).

Controlling the shadow part of the official GDP will not reduce the level of the Ukrainian shadow economy. It should be done by the legislative increasing to the level of highly developed countries of the payroll share in the output. The payroll share should rise from the concealed part of GDP. However, at the same time, Ukraine needs to eradicate corruption, reduce taxes and redistribute social responsibility. Thus, the shadow economy can be a very important reserve for economic growth (Kharazishvili, 2017).

The analysis of the problems concerning the shadow payroll decrease in Ukraine has shown that it is relevant to determine the reserves of tax revenues growth and possibilities of covering the Ukrainian Pension Fund deficit by taxing the hidden payroll. Aforementioned will enable discovering how much wage legalization can help the state in the current circumstances.

The purpose of the paper is to consider the reserves for the payroll taxes increase by reducing shadow wages of employees and introducing measures to improve payroll taxation in Ukraine.

\section{SURVEY METHODOLOGY}

The current mechanism of payroll taxation in Ukraine includes the collection of the unified social contribution (USC), personal income tax (PIT) and military levy (ML).

The survey methodology involves analyzing the reformation of payroll taxation mechanism in Ukraine, identifying wage differences of the employees in large, medium-sized and small business, estimating the possibilities for increasing tax revenues and covering the deficit of the Pension Fund of Ukraine by decreasing shadow wages and improving payroll taxation in Ukraine.

While conducting the research, we have utilized official statistic data from the International Monetary Fund, the European Commission, the State Treasury Service of Ukraine, the State Fiscal Service of Ukraine, the State Statistics Service of Ukraine, the Ministry of Economic Development and Trade of Ukraine, the Pension Fund of Ukraine and 
DOI: 10.14807/ijmp.v12i2.1297

the National Bank of Ukraine, large business entities in Ukraine, as well as took into account Ukrainian tax legislation.

We paid significant attention to the salaries of the top managers of large business entities as a possible basis for applying progressive taxation of personal income. We assumed that the salaries of senior management of large entities exceed the maximum limit of charging a unified social contribution in Ukraine.

The number of top managers in a large company depends on its organizational structure, the distribution of rights and responsibilities among managers at different levels. The most typical positions of the top managers of large companies include the following: Chief Executive Officer (CEO); Chief Financial Officer (CFO); Chief Visionary Officer (CVO); Chief Operating Officer (COO); Chief Information Officer (CIO); Chief Security Officer (CSO); Chief Marketing Officer (CMO); Chief Information Security Officer (CISO); Chief Accounting Officer (CAO); Chief Technical Officer (CTO).

The list of positions is not limited to the abovementioned and it can vary at different legal entities.

To determine the average number of top managers per large business entity in Ukraine we applied a sampling method. In particular, we have collected data on the number of top managers in 82 entities (15.7\% of the entire population) that worked successfully in 2018 and published the information about their management. The interpretation of the data presented that, on average, a large Ukrainian business entity hires approximately 10 top managers (exact value was 9.5). The standard deviation of the sample was 2.9; dispersion - 8.3; limiting error - 0.6 (95.4\% probability); relative error - 3.1\%; coefficient of variation - 30.2\%. These indicators make it possible to conclude that the sample is representative, the population is homogeneous, and the average is the typical characteristic of the population.

The top manager's average monthly salary (AMS) in 2012-2018 was calculated using the following formula:

$$
A M S=L+P_{e x}: 12: m: n
$$

here $L$ - the maximum Unified Social Contribution base in Ukraine; $P_{e x}-$ the annual payroll in the economy that exceeded the maximum base of the Unified Social Contribution; $m$ - the number of top managers per large business entity (for 2012-2018 we used $m=10$, calculated based on sampling); $n$ - the number of large business entities. 
DOI: 10.14807/ijmp.v12i2.1297

When calculating tax revenue reserves from the payroll, we took into account the actual Personal Income Tax and Unified Social Contribution rates in 2012-2018, in particular, the actual annual tax revenues to the tax base ratio. The reserves of the USC revenues take into account the revenues from the payroll, which exceeded the maximum USC base in Ukraine, as well as the USC revenues from the possible amount of the legalized payroll. The reserves of the PIT revenues were calculated at the average rate of this tax from a possible legalized payroll and included top managers' payroll taxes at the recommended rate of $32 \%$. We have applied this rate to a monthly salary of over 15 minimum wages.

\section{RESULTS AND DISCUSSIONS}

\subsection{Payroll tax reforms and shadow economy in Ukraine}

During 2001-2010, economic entities paid four types of social payroll taxes, and since January 1, 2011, they have been included in the Unified Social Contribution (USC). The base for the USC for employers was capped according to their occupational risk classes, taking into account their economic activities, i.e. the contribution rate ranged from $36.76 \%$ for the first class to $49.7 \%$ for the 67 th occupational risk class. Employees of enterprises paid a Unified Social Contribution of 3.6\%.

From 1998 to 2005, the cap of charging the Unified Social Contribution varied from 1000 to 4100 UAH. In 2006, it was set at 10 times the subsistence minimum set for the ablebodied individuals. During 2007-2010, the cap was set at 15, and from 2011 to 2015 it was set at 17 times the subsistence minimum set for the able-bodied persons. In 2016 the maximum base of charging the Unified Social Contribution was raised to 25 times the minimum wage of subsistence set for the able-bodied persons, and since January 1, 2018, it was capped to 15 times the minimum wages.

Concerning the payroll taxation, from the beginning of Independence and until 2004, the collection of Personal Income Tax in Ukraine was progressive. The rates were 10, 15, 20, 30 and 40\% with the existence of a non-taxable limit. For the years 2004-2006, the Personal Income Tax rate was 13\%. During 2007-2010, a total tax rate of 15\% was set. With the adoption of the Tax Code, on January 3, 2011, Personal Income Tax started to be deducted from the payroll at the rates of 15 and $17 \%$.

On August 3, 2014, a military levy with a deduction rate of 1.5\% from the payroll was imposed and it is still valid. 


\section{INDEPENDENT JOURNAL OF MANAGEMENT \& PRODUCTION (IJM\&P)}

http://www.ijmp.jor.br

v. 12, n. 2, March-April 2021

ISSN: 2236-269X

DOI: 10.14807/ijmp.v12i2.1297

On January 1, 2015, the increased Personal Income Tax rate grew from 17 to 20\%. Besides, the government started defining the rate of the USC charges taking into consideration the lowering factor, but its application has proved to be burdensome for most employers.

On January 1, 2016, the government set the basic Personal Income Tax rate at 18\% for the entire tax base, regardless of its size. It also set a single USC rate of $22 \%$ (except for the wages for disabled persons), abolished the USC deduction from employees' wage and the determination of occupational risk class for employers.

Table 1 summarizes information about the payroll tax rates in Ukraine.

Table 1: Payroll tax rates in Ukraine from 2007 to 2018, \%

\begin{tabular}{|c|c|c|c|c|c|c|c|c|c|c|c|c|}
\hline \multirow{2}{*}{ 氕 } & \multicolumn{12}{|c|}{ Years } \\
\hline & 옹 & 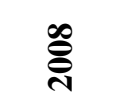 & ஓి & 웅 & 콩 & 궁 & $\stackrel{n}{\stackrel{N}{2}}$ & $\underset{⿱ 亠 乂}{\Delta}$ & 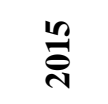 & $\stackrel{0}{\circ}$ & 공 & $\stackrel{\infty}{\stackrel{1}{人}}$ \\
\hline \multicolumn{13}{|c|}{ Tax accruals } \\
\hline PFU & $4-42$ & $4-42$ & $4-42$ & $4-42$ & - & - & - & - & - & - & - & - \\
\hline DIF & $0.5-1.5$ & $0.5-1.5$ & $0.5-1.4$ & $0.5-1.4$ & - & - & - & - & - & - & - & - \\
\hline UIF & $0-1.3$ & $0-1.3$ & $0-2.2$ & $0-2.2$ & - & - & - & - & - & - & - & - \\
\hline AIF & $\begin{array}{c}0.66- \\
13.6\end{array}$ & $\begin{array}{c}0.66- \\
13.6\end{array}$ & $\begin{array}{c}0.66- \\
13.6\end{array}$ & $\begin{array}{c}0.66- \\
13.6\end{array}$ & - & - & - & - & - & - & - & - \\
\hline RUSC & - & - & - & - & $\begin{array}{c}8.41- \\
49.7\end{array}$ & $\begin{array}{c}8.41- \\
49.7\end{array}$ & $\begin{array}{c}8.41- \\
49.7\end{array}$ & $\begin{array}{c}8.41- \\
49.7\end{array}$ & $\begin{array}{c}8.41- \\
49.7\end{array}$ & 22 & 22 & 22 \\
\hline TA & $\begin{array}{c}5.16- \\
58.4\end{array}$ & $\begin{array}{l}5.16- \\
58.4\end{array}$ & $\begin{array}{l}5.16- \\
59.2\end{array}$ & $\begin{array}{c}5.16- \\
59.2\end{array}$ & $\begin{array}{c}8.41- \\
49.7\end{array}$ & $\begin{array}{c}8.41- \\
49.7\end{array}$ & $\begin{array}{c}8.41- \\
49.7\end{array}$ & $\begin{array}{c}8.41- \\
49.7\end{array}$ & $\begin{array}{c}8.41- \\
49.7\end{array}$ & 22 & 22 & 22 \\
\hline \multicolumn{13}{|c|}{ Tax deductions } \\
\hline PFU & $0.5-5$ & $2-5$ & $2-5$ & $2-5$ & 2.6-6.1 & 2.6-6.1 & 2.6-6.1 & - & - & - & - & - \\
\hline DIF & $0.25-1$ & $0.25-1$ & $0.25-1$ & $0.25-1$ & - & - & - & - & - & - & - & - \\
\hline UIF & 0.5 & 0.5 & 0.6 & 0.6 & - & - & - & - & - & - & - & - \\
\hline RPIT & 15 & 15 & 15 & 15 & $15 ; 17$ & $15 ; 17$ & $15 ; 17$ & $15 ; 17$ & $15 ; 20$ & 18 & 18 & 18 \\
\hline RML & - & - & - & - & - & - & - & 1.5 & 1.5 & 1.5 & 1.5 & 1.5 \\
\hline TD & $\begin{array}{c}16.25- \\
21.5\end{array}$ & $\begin{array}{c}17.75- \\
21.5\end{array}$ & $\begin{array}{c}17.85- \\
20.6\end{array}$ & $\begin{array}{c}17.85- \\
20.6\end{array}$ & $\begin{array}{l}17.6- \\
20.1\end{array}$ & $\begin{array}{l}17.6- \\
21.1\end{array}$ & $\begin{array}{l}17.6- \\
21.1\end{array}$ & $\begin{array}{l}16.5 \\
18.5\end{array}$ & $\begin{array}{l}16.5 \\
21.5\end{array}$ & 19.5 & 19.5 & 19.5 \\
\hline TRPT & $\begin{array}{c}21.41- \\
79.9\end{array}$ & $\begin{array}{c}22.91- \\
79.9\end{array}$ & $\begin{array}{c}23.01- \\
79.8\end{array}$ & $\begin{array}{c}23.01- \\
79.8\end{array}$ & $\begin{array}{c}26.01- \\
69.8\end{array}$ & $\begin{array}{c}26.01- \\
70.8\end{array}$ & $\begin{array}{c}26.01- \\
70.8\end{array}$ & $\begin{array}{c}24.91- \\
68.2\end{array}$ & $\begin{array}{c}24.91- \\
71.2\end{array}$ & 41.5 & 41.5 & 41.5 \\
\hline
\end{tabular}

Note: PFU - the rate of social contribution to the Pension Fund of Ukraine; AIF - the rate of social contribution to the Accident Insurance Fund of Ukraine; UIF - the rate of social contribution to the Unemployment Insurance Fund of Ukraine; DIF - the rate of social contribution to the Disability Insurance Fund of Ukraine; RUSC - the rate of the Unified Social Contribution; TA - the total rate of tax accruals; RPIT - the rate of Personal Income Tax; RML - the rate of the military levy; TD - the total rate of tax deductions; TRPT - the total rate of payroll taxes.

Source: Authors' summarizing is based on Ukrainian tax legislation. 
DOI: 10.14807/ijmp.v12i2.1297

The Pension Fund of Ukraine was established in 1990, the Accident Insurance Fund of Ukraine and the Unemployment Insurance Fund of Ukraine were created in 2000, and the Disability Insurance Fund of Ukraine began its activity in 2001. All of these social funds simultaneously started to receive social security contributions starting from 2001.

Till January 1, 2011, economic entities paid four different types of social taxes from payroll, and each fund administered its social tax separately. Social taxes included pension insurance contribution, disability insurance contribution, unemployment insurance contribution and accident insurance contribution.

From January 1, 2011, social taxes were consolidated into the Unified Social Contribution and the Pension Fund of Ukraine started its administration. At the same time, the other three social funds continued to perform the rest of the functions. From October 1, 2013, the administration of the Unified Social Contribution was transferred to the Ministry of Income and Fees, and from May 21, 2014, the State Fiscal Service of Ukraine started to manage the mentioned contribution.

In general, the deficit problem is especially urgent for the Pension Fund, burdening the state budget year after year. Not only the subsidies to cover the deficit and short-term loans are assigned to the Pension Fund from the state budget, but it also funds the grants for pension payments, allowances and raises to pensions that were appointed under different pension programs, etc. The Pension Fund also receives some costs from other social security funds. In 2007, expenditures of the Pension Fund exceeded its revenues by UAH 24.4 billion, while in 2018, it grew to UAH 156.6 billion, which means that the deficit rose 6 more times.

The importance of payroll tax reforms is predetermined by the fact that payroll taxes dominate in the structure of tax revenues in Ukraine (Figure 1).

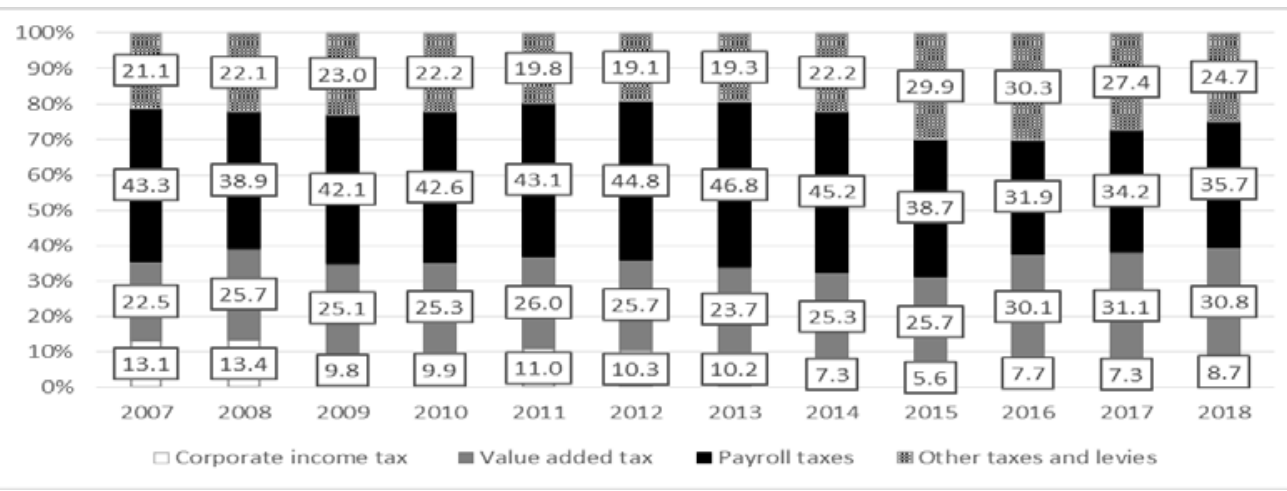

Figure 1: The structure of tax revenues in Ukraine during 2007-2018

Source: Authors' calculations based on the data from IMF, the State Treasury Service of Ukraine and the State Fiscal Service of Ukraine. 
DOI: 10.14807/ijmp.v12i2.1297

In particular, in 2010-2018, the share of payroll taxes varied from $46.8 \%$ to $31.9 \%$. The decrease in the rates of the Unified Social Contribution and Personal Income Tax from payroll caused a sharp downturn in 2016. However, then payroll tax share began to grow, reaching $35.7 \%$ in 2018. Thus, payroll taxes formed the largest part of tax revenues, compared to a value-added tax, a corporate income tax and other taxes and levies. This demonstrates the highest fiscal importance of the payroll as a tax base in the Ukrainian economy.

Due to the lack of tax revenues, the Ministry of Economic Development and Trade regularly calculates the level of the shadow economy in Ukraine. For this purpose, the Ministry applies such methods as "population expenditures - retail turnover"; electricity method; monetary method; loss-making enterprises method, and the analysis of an integral indicator of the level of the shadow economy. The highest level of the shadow economy is obtained through the method of "population expenditures - retail turnover", but the Ministry notes that only an integral indicator of the level of the shadow economy can serve a complex index that fully characterizes such a phenomenon as the shadow economy (Figure 2).

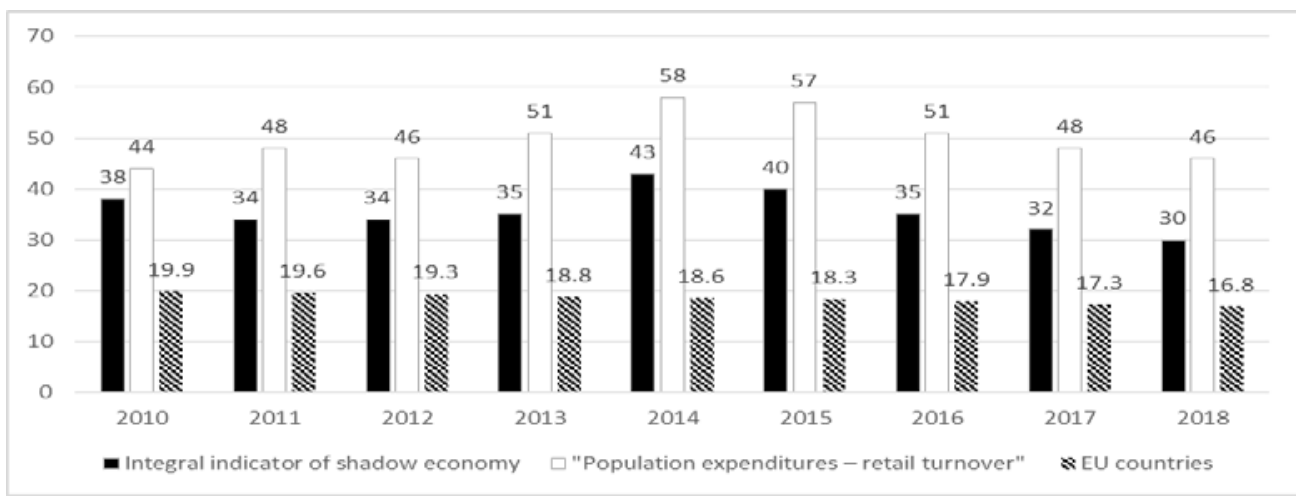

Figure 2: The level of the shadow economy in Ukraine defined by different methods in 20102018, the percentage of official GDP

Source: Data from F. Schneider and the Ministry of Economic Development and Trade of Ukraine.

According to the mentioned data, in 2010-2018 the highest level of the shadow economy was observed in 2014 and 2015, which was accompanied by a worsening of the overall economic situation in the country due to the start of military actions in the Eastern part of the country. Since 2016, the level of shadowing has begun to decline at one time with the introduction of a reduced Unified Social Contribution rate of $22 \%$ and the abolishment of the progressive taxation of personal income with imposing a proportional rate of $18 \%$. Also, in 2010-2018, Ukraine had a much higher level of the shadow economy than the EU countries (2-3 times higher). 
INDEPENDENT JOURNAL OF MANAGEMENT \& PRODUCTION (IJM\&P)

http://www.ijmp.jor.br

v. 12, n. 2, March-April 2021

ISSN: 2236-269X

DOI: 10.14807/ijmp.v12i2.1297

As for the recent planned changes in payroll taxation, starting from January 2020, the Verkhovna Rada of Ukraine has been considering a bill concerning the progressive taxation scale for the calculation of Personal Income Tax. The following changes are suggested:

1) for the income up to 10 times a minimum wage the current rate of $18 \%$ is proposed;

2) for the income more than 10 times a minimum wage, but no more than 20 times, a minimum wage of $36 \%$ is proposed;

3) for the income over 20 times a minimum wage - 54\%.

\subsection{Formation of wages in Ukraine}

Suggestions to return to progressive taxation of personal income are justified by the fact that in most EU countries the rate of personal income differs and depends on the level of the income received. Therefore, to determine the consequences of such an implementation, it is necessary to investigate more thoroughly the size of wages in Ukraine and the experience of the EU countries.

At first, it is worth examining the average wage in Ukraine (Table 2). According to the mentioned data, in 2007-2019, the nominal average and minimum wage, denominated in the national currency (UAH), have increased.

Table 2: The average and the minimum wage in Ukraine per month in 2007-2019

\begin{tabular}{|c|c|c|c|c|}
\hline Years & $\begin{array}{c}\text { The average wage, } \\
\text { UAH }\end{array}$ & $\begin{array}{c}\text { Minimum wage, } \\
\text { UAH }\end{array}$ & $\begin{array}{c}\text { The average } \\
\text { wage, USD }\end{array}$ & $\begin{array}{c}\text { Minimum wage, } \\
\text { USD }\end{array}$ \\
\hline 2007 & 1,351 & 430 & 268 & 85 \\
\hline 2008 & 1,806 & 533 & 283 & 84 \\
\hline 2009 & 1,906 & 643 & 238 & 111 \\
\hline 2010 & 2,239 & 888 & 281 & 121 \\
\hline 2011 & 2,633 & 963 & 330 & 137 \\
\hline 2012 & 3,026 & 1,098 & 379 & 144 \\
\hline 2013 & 3,265 & 1,153 & 409 & 64 \\
\hline 2014 & 3,480 & 1,248 & 293 & 56 \\
\hline 2015 & 4,195 & 1,271 & 211 & 116 \\
\hline 2016 & 5,183 & 1,439 & 202 & 134 \\
\hline 2018 & 7,104 & 3,200 & 257 & 159 \\
\hline 2019 & 8,865 & 3,723 & 318 & 399 \\
\hline
\end{tabular}

Source: Authors' calculations based on the data from the State Statistics Service of Ukraine, the National Bank of Ukraine and Ukrainian tax legislation.

The average wage exceeded 3.6 to 2.2 times the minimum wage. This was caused by the income differentiation among the Ukrainian population, in particular, in $2018,71 \%$ of the population had incomes less than 5160 UAH (185 USD) per month, while 29\% had more than 5160 UAH or 185 USD per month. Taking into account the changes in the exchange rate, the average wage was the highest in 2013 (409 USD), and then it began to decline in 2014-2016. 
DOI: 10.14807/ijmp.v12i2.1297

Growth resumed in 2017, and in 2019 the wage reached 399 USD due to the revaluation of the hryvnia.

Employing the analysis, it is worth investigating the business entities that form the largest share of the payroll in Ukraine (Figure 3).

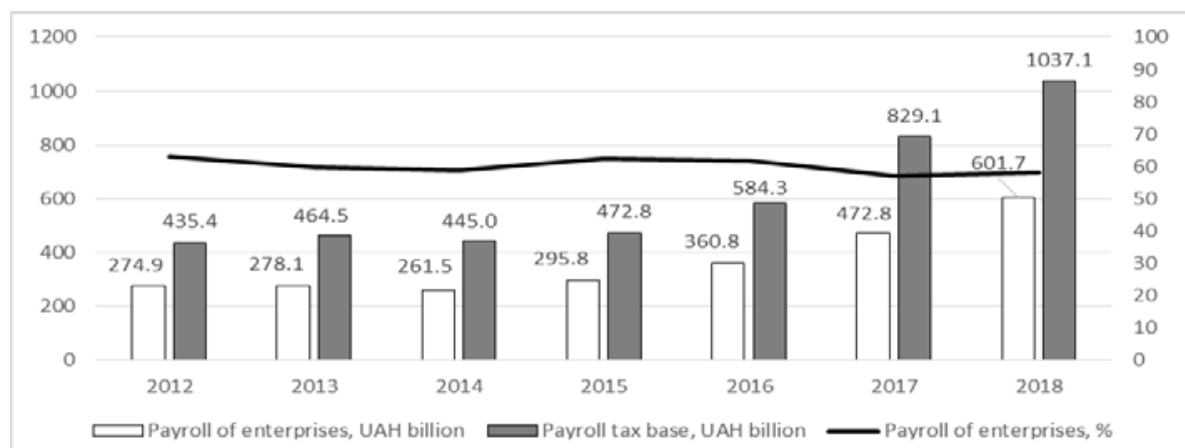

Figure 3: The share of enterprises in the formation of payroll in Ukraine during 2012-2018 Source: Authors' calculations based on the data from the State Statistics Service of Ukraine and the State Fiscal Service of Ukraine.

The structure of payroll by type of economic entity convinces that the share of enterprises' payroll remained dominant and formed more than $50 \%$ of the total payroll in the economy.

In 2012, the share of enterprises' payroll constituted 63.1\% of the payroll tax base, while in 2018 it decreased to 58\%. On average, in 2012-2018, the payroll of enterprises was $60 \%$, while payroll of banks, budgetary institutions, individual entrepreneurs and legal entities engaged in non-profit activities amounted to $40 \%$.

Today, the Ukrainian business sector is represented by large, medium-sized and small business entities (including microenterprises) operating in various fields and sectors of economic activity. The study of the enterprises’ payroll structure taking into account the entity size showed that large and medium-sized enterprises had the biggest payroll share. This seems natural as they have a much greater financial capacity and economic activity than other entities. During 2012-2018, the share of the payroll of large enterprises decreased from 45.4 to 38.6\%. At the same time, the share of medium-sized enterprises increased from 38.9 to $44.3 \%$ and the small ones - from 15.7 to $17.1 \%$ (Figure 4). 


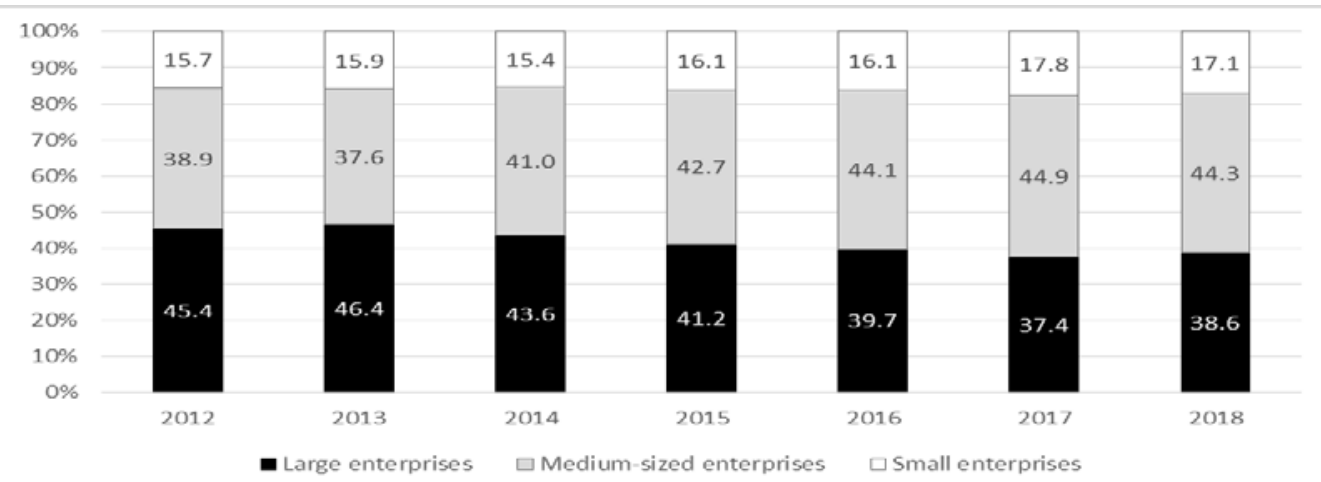

Figure 4: Structure of the enterprises’ payroll by entity size in Ukraine during 2012-2018

Source: Authors' calculations based on the data from the State Statistics Service of Ukraine.

Large and medium-sized businesses together formed the biggest share of the payroll of Ukrainian enterprises, which made $82.9 \%$ in 2018. At the same time, large enterprises paid the highest wages, while employees of medium-sized and small enterprises were paid less than the average wage (Figure 5).

Thus, the progressive taxation of personal income can be applied only to the payroll of large business entities in Ukraine. However, it is worth determining how much tax revenue can increase after the imposing of progressive taxation.

In our opinion, in Ukraine, the payroll of top managers of large business entities is the main base to apply progressive taxation to. Official statistics about the salaries of this employee category is absent in Ukraine. At the same time, there are expert reviews of domestic media and research of international headhunting companies. As a result, the ranking of the highestpaid managers in Ukraine is published annually, which includes a survey based on the sampling of the existing companies and deals only with the salaries of CEOs (Presidents).

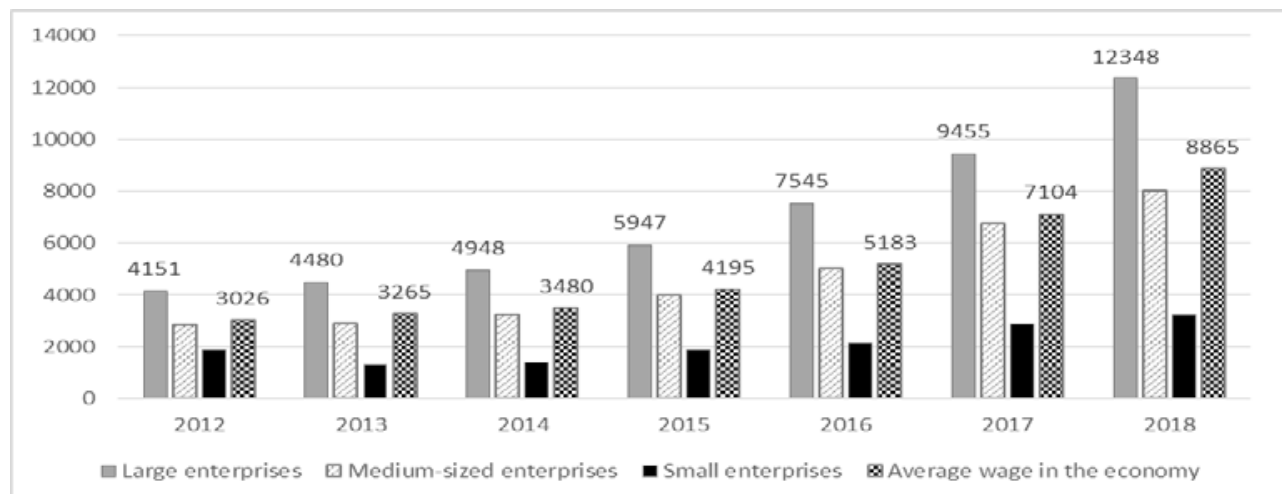

Figure 5: Average monthly wage at enterprises and in the economy of Ukraine in 2012-2018, UAH.

Source: Data from the State Statistics Service of Ukraine. 
INDEPENDENT JOURNAL OF MANAGEMENT \& PRODUCTION (IJM\&P)

http://www.ijmp.jor.br

v. 12, n. 2, March-April 2021

ISSN: 2236-269X

DOI: 10.14807/ijmp.v12i2.1297

In our survey, we have calculated the average salary of all of the top managers of large business entities and compared it with the minimum wage in Ukraine (Table 3).

Table 3: Average monthly salary of a top manager in a large business entity in Ukraine during 2012-2018

\begin{tabular}{|l|r|r|r|r|r|r|r|}
\hline Indicator & $\mathbf{2 0 1 2}$ & $\mathbf{2 0 1 3}$ & $\mathbf{2 0 1 4}$ & $\mathbf{2 0 1 5}$ & $\mathbf{2 0 1 6}$ & $\mathbf{2 0 1 7}$ & $\mathbf{2 0 1 8}$ \\
\hline Total payroll, UAH billion & 457.2 & 487.4 & 471.7 & 512.4 & 627.9 & 864.2 & 1067.9 \\
\hline $\begin{array}{l}\text { Payroll exceeding maximum USC base, UAH } \\
\text { billion }\end{array}$ & 21.8 & 22.9 & 26.6 & 39.7 & 43.6 & 35.1 & 30.8 \\
\hline Number of large business entities, units & 874 & 839 & 660 & 540 & 479 & 481 & 523 \\
\hline Maximum USC base, UAH thousand & 18.7 & 19.6 & 21.2 & 21.6 & 36.0 & 41.6 & 55.8 \\
\hline Top manager's monthly salary, UAH thousand & 226.5 & 247.1 & 357.1 & 634.3 & 794.5 & 649.7 & 546.6 \\
\hline Top manager's monthly salary, USD thousand & 28.4 & 30.9 & 30.1 & 31.9 & 31.0 & 23.5 & 19.6 \\
\hline Top manager's salary to minimum wage ratio & 206.3 & 214.3 & 286.1 & 499.0 & 552.1 & 203.0 & 146.8 \\
\hline Top manager's salary to average wage ratio & 74.9 & 75.7 & 102.6 & 151.2 & 153.3 & 91.5 & 61.7 \\
\hline
\end{tabular}

Source: Authors' calculations based on the data from the State Statistics Service of Ukraine, the State Fiscal

Service of Ukraine, the National Bank of Ukraine and the websites of large business entities (enterprises and banks) in Ukraine

According to the calculations, in 2012-2018, the monthly salary of a top manager ranged from UAH 226.5 to UAH 794.5 thousand (USD 20-32 thousand). The salary of a top manager was from 552 to 147 times above the minimum wage and from 153 to 62 times above the average wage in Ukraine. Increase of the 2 times the minimum wage, which happened in 2017, caused the reduction in the discrepancy.

Thus, the salaries of Ukraine's top managers meet the criteria of applying the progressive taxation of personal income and imposing the highest personal income tax rate and are currently proposed in the draft law for approval.

\subsection{Estimation of payroll tax revenue reserves in Ukraine}

A study of the EU countries experience showed that in early 2019, high progressive rates of personal income tax from payroll were inherent in Austria (55\%), Belgium (50\%), the Netherlands (52\%) and Slovenia (50\%). However, these rates were applied to a higher income than the one offered in the draft law of Ukraine. Besides, the maximum Personal Income Tax rate among most EU countries was below 50\%. Among the post-socialist new EU member states, the majority applied progressive taxation, while the smaller part had proportional taxation. In particular, the following rates of personal income tax were observed: Slovenia (16\%; 27\%; 34\%; 39\%; 50\%), Latvia (20\%; 23\%; 31.4\%), Poland (18\%; 32\%), Lithuania (20\%; 27\%), Slovakia (19\%; 25\%), Croatia (24\%; 36\%), Czech Republic (15\%), Estonia (20\%), Hungary (15\%), Romania (10\%), Bulgaria (10\%). In Ukraine, this rate was 18\% for 
DOI: 10.14807/ijmp.v12i2.1297

payroll. Also, over the last 7 years, the Czech Republic, Estonia, Hungary and Romania have reduced the personal income tax rates.

We suggest that while setting the maximum progressive rate of the Personal Income Tax, Ukraine should focus primarily on the experience of the post-socialist new EU member states, as they are the closest to Ukraine when considering the historical aspect of their development. Thus, we can see that the maximum Personal Income Tax rate is not $54 \%$ in these countries. Taking into account the discrepancy between the salaries of top managers and the minimum and the average wages in Ukraine, we consider returning to progressive taxation as advisable. Also, the current Personal Income Tax rate in Ukraine (18\%) coincides with the basic rate of the same tax in Poland. Therefore, we recommend using Polish experience when reforming payroll taxation in Ukraine, in particular setting the second progressive rate at 32\%. Considering the amount of income when applying progressive taxation in Poland, we propose to apply the following tax rates of the Personal Income Tax from payroll in Ukraine:

a) for the monthly wage up to 15 times the minimum wage the current rate of $18 \%$ is proposed;

b) for the monthly wage over 15 minimum wages - 32\% respectively.

The highest tax rate will provide tax revenues primarily from the salaries of top managers in Ukraine. We consider the proposed reform, which implies the application of three Personal Income Tax rates of 18, 36 and 54\%, too burdensome for Ukraine, given the significant level of the shadow economy.

However, in the context of the need for tax revenues in Ukraine, it is also necessary to abolish the maximum base for calculating the Unified Social Contribution, which is necessary for supplying the state social security funds at the expenses of the salary of the top managers of large business entities.

The next step of the study is to determine the reserves of increasing payroll tax revenues in Ukraine due to the introduction of the second progressive Personal Income Tax rate of 32\%, to abolish the maximum USC base from the payroll and reducing the shadow economy of Ukraine to the level of the EU countries (Table 4).

Table 4: Reserves of increasing payroll tax revenues in Ukraine during 2012-2018

\begin{tabular}{|l|r|r|r|r|r|r|r|}
\hline Indicator & $\mathbf{2 0 1 2}$ & $\mathbf{2 0 1 3}$ & $\mathbf{2 0 1 4}$ & $\mathbf{2 0 1 5}$ & $\mathbf{2 0 1 6}$ & $\mathbf{2 0 1 7}$ & $\mathbf{2 0 1 8}$ \\
\hline Total payroll, UAH billion & 457.2 & 487.4 & 471.7 & 512.4 & 627.9 & 864.2 & 1067.9 \\
\hline $\begin{array}{l}\text { The level of the shadow economy in } \\
\text { Ukraine, \% }\end{array}$ & 34.0 & 35.0 & 43.0 & 40.0 & 35.0 & 32.0 & 30.0 \\
\hline Shadow payroll, UAH billion & 155.5 & 170.6 & 202.8 & 205.0 & 219.8 & 276.5 & 320.4 \\
\hline
\end{tabular}


INDEPENDENT JOURNAL OF MANAGEMENT \& PRODUCTION (IJM\&P)

http://www.ijmp.jor.br

v. 12, n. 2, March-April 2021

ISSN: 2236-269X

DOI: 10.14807/ijmp.v12i2.1297

\begin{tabular}{|l|r|r|r|r|r|r|r|}
\hline $\begin{array}{l}\text { The level of the shadow economy in } \\
\text { the EU countries,\% }\end{array}$ & 19.3 & 18.8 & 18.6 & 18.3 & 17.9 & 17.3 & 16.8 \\
\hline $\begin{array}{l}\text { Reduction in the shadow payroll, } \\
\text { UAH billion }\end{array}$ & 67.2 & 79.0 & 115.1 & 111.2 & 107.4 & 127.0 & 141.0 \\
\hline Average USC rate, \% & 36.6 & 36.2 & 36.4 & 35.1 & 21.6 & 21.6 & 21.2 \\
\hline Average PIT rate, \% & 13.8 & 13.6 & 13.7 & 14.3 & 16.9 & 17.3 & 17.5 \\
\hline $\begin{array}{l}\text { Reserves of USC revenues, UAH } \\
\text { billion }\end{array}$ & 32.5 & 36.9 & 51.5 & 52.9 & 32.6 & 35.0 & 36.4 \\
\hline $\begin{array}{l}\text { Reserves of PIT revenues, UAH } \\
\text { billion }\end{array}$ & 13.3 & 15.0 & 20.6 & 23.0 & 24.9 & 27.1 & 29.1 \\
\hline $\begin{array}{l}\text { Total reserves of payroll tax } \\
\text { revenues, UAH billion }\end{array}$ & 45.8 & 51.9 & 72.1 & 75.9 & 57.4 & 62.0 & 65.6 \\
\hline $\begin{array}{l}\text { The deficit of the Pension Fund of } \\
\text { Ukraine, UAH billion }\end{array}$ & 75.7 & 83.4 & 77.6 & 95.8 & 141.7 & 132.6 & 156.6 \\
\hline $\begin{array}{l}\text { Deficit coverage of the Pension Fund } \\
\text { of Ukraine, \% }\end{array}$ & 60.5 & 62.2 & 93.0 & 79.2 & 40.5 & 46.8 & 41.9 \\
\hline
\end{tabular}

Source: Authors' calculations based on the data from the State Statistics Service of Ukraine, the State Fiscal

Service of Ukraine, the European Commission and the Ministry of Economic Development and Trade of Ukraine.

As the calculations showed, there are some reserves for the partial overcoming of the Pension Fund deficit in Ukraine. In particular, in 2014, they were at a maximum of 93\%, whereas since 2016 they have decreased, reaching 42\% of the deficit in 2018. The reason was a significant reduction in the unified social contribution rate to $22 \%$ in 2016 .

However, an important factor in the calculation of reserves is the reduction of the Ukrainian shadow economy, which is quite a difficult task, since economic entities do not fully trust the government policy and the accuracy of its managerial decisions. Therefore, if the level of shadowing does not decrease, it will be practically impossible to overcome the deficit of the Pension Fund of Ukraine. Even with the best option of reducing the shadowing, it is possible to cover deficit only partially. This proves that in Ukraine it is necessary to ensure economic growth and increase in wages.

\section{CONCLUSIONS}

The measures to increase payroll tax revenues and reduce the deficit of the Pension Fund of Ukraine should include:

- imposing the second progressive PIT rate of 32\% for a monthly income over 15 minimum wages and abolishment of the maximum USC base;

- reducing the level of the shadow economy by forming public confidence in government ability to conduct correct policy and use of accumulated tax funds appropriately;

- stimulating economic growth to increase wages, stabilization of the tax legislation and counteracting excessive cyclical fluctuations in the economic environment.

\section{REFERENCES}


Boreiko, V. I. (2015) Shliakhy vyvedennia zarobitnoi platy z «tini» [Ways of removing wage from the «shadow»]. Herald of Economic Science of Ukraine, 2(29), 3-6.

Danylyshyn, V. I., \& Stefankiv, O. M. (2011) Tinovi zarobitni platy: prychyny, obsiahy ta shliakhy detinizatsii [Informal wage: causes, scope and ways of legalization]. Journal Efektyvna ekonomika, (8). Available at: http://www.economy.nayka.com.ua/?op=1\&z=658. Access: 13th February 2020.

Kharazishvili, Yu. M. (2017) Svitlo i tin ekonomiky Ukrainy: rezervy zrostannia ta modernizatsii [Light and shadow of the economy of Ukraine: reserves for growth and modernization]. The Economy of Ukraine, 4(665), p. 22-45.

Kulikov, H. T. (2016) Detinizatsiia zarobitnoi platy naimanykh pratsivnykiv [De-shadowing of Employees' Wages]. Labour market and employment: journal of Training Institute of the State, 4, 13-17.

Sanduhei, V. V. (2017) Detinizatsiia vitchyznianoho rynku pratsi yak neobkhidna umova efektyvnoi yevrointehratsii [Deshadowing Domestic Labor Market as a Prerequisite Effective Integration]. Market infrastructure, 3, 11-15. Available at: http://marketinfr.od.ua/journals/2017/3_2017_ukr/3_2017.pdf. Access: 13th February 2020.

Schneider, F. (2019) Size of the Shadow Economies of 28 European Union Countries from 2013 to 2018. The Latest Development, in VLACHOS, V; BITZENIS, A. (Eds.), European Union. Post Crisis Challenges and Prospects for Growth. London: Palgrave Macmillan, 111-122. 